\title{
SPATIAL AND TEMPORAL VARIABILITY OF LEAF WETNESS DURATION IN THE STATE OF SÃO PAULO, BRAZIL
}

\author{
Emília Hamada ${ }^{1 *}$; Raquel Ghini ${ }^{1}$; Jeferson Lobato Fernandes²; Mário José Pedro Júnior³ \\ Paulo Rossi ${ }^{4}$ \\ Embrapa Meio Ambiente, C.P. 69 - 13820-000 - Jaguariúna, SP - Brasil. \\ ${ }^{2}$ UNICAMP/FEAGRI, Programa de Pós-Graduação em Planejamento e Desenvolvimento Rural Sustentável, \\ C.P. 6011 - 13083-875 - Campinas, SP - Brasil. \\ IAC/APTA/SAA, C.P. 28 - 13012-970 - Campinas, SP - Brasil. \\ ${ }^{4}$ Embrapa Cerrados, C.P. 08223 - 73310-970 - Planaltina, DF - Brasil. \\ *Corresponding author 〈emilia@cnpma.embrapa.br>
}

\begin{abstract}
One of the main factors influencing the occurrence of plant diseases is the leaf wetness duration (LWD). However, this climatic parameter is not generally and systematically recorded at meteorological stations, and the alternative to obtain an estimate for LWD is the use of mathematical models. The objective of this study was to estimate LWD for the State of São Paulo, on the basis of the number of hours with relative humidity equal to or higher than $90 \%$, and also plot them on a map with help of the Geographical Information System (GIS) tool. Using daily relative humidity data from ten meteorological stations of the State, for six years, adjustment equations were obtained for different LWD periods (hours day $\left.{ }^{-1}\right)\left(\mathrm{R}^{2}\right.$ from 0.58 to 0.81 ) and of number of days (ND) per month with LWD for a period equal to or higher than ten consecutive hours ( $\mathrm{R}^{2}$ from 0.57 to 0.75 ), both as functions of the mean relative humidity. The mean LWD and the mean ND varied among the different regions of the State and different periods of the year. The smallest estimated values of mean annual LWD and ND were observed for the west region of the State, and the highest values for the coastal region.
\end{abstract}

Key words: plant diseases, relative humidity, Geographical Information System, regression equation

\section{VARIABILIDADE ESPACIAL E TEMPORAL DA DURAÇÃO DO PERÍODO DE MOLHAMENTO FOLIAR NO ESTADO DE SÃO PAULO, BRASIL}

\begin{abstract}
RESUMO: A duração do período de molhamento (DPM) foliar é um dos principais fatores para a ocorrência de doenças de planta. No entanto, esse parâmetro climático não é geralmente registrado sistematicamente nas estações meteorológicas, tendo-se como alternativa estimar a DPM por meio de modelos matemáticos. Este trabalho teve como objetivo estimar a DPM para o estado de São Paulo, baseando-se no número de horas com umidade relativa igual ou superior a $90 \%$, e também espacializá-la utilizando as ferramentas de Sistema de Informações Geográficas (SIG). Utilizando resultados diários de umidade relativa de dez estações meteorológicas do estado, de seis anos, foram obtidas para diferentes períodos as equações de ajuste de DPM (horas $\left.\operatorname{dia}^{-1}\right)\left(\mathrm{R}^{2}\right.$ de 0,58 a 0,81 ) e de número de dias (ND) ao mês com DPM por um período igual ou superior a dez horas consecutivas $\left(\mathrm{R}^{2}\right.$ de 0,57 a 0,75$)$, ambas em função da umidade relativa média. A DPM média e ND média variaram entre as regiões do estado e nos períodos do ano. Os menores valores estimados de DPM e de ND médias anuais foram observados na região oeste do estado e os maiores valores na região litorânea.

Palavras-chave: doenças de plantas, umidade relativa, Sistema de Informações Geográficas, equação de regressão
\end{abstract}

\section{INTRODUCTION}

Leaf wetness can be defined as water in liquid form present on the surface of leaves (Klemm et al., 2002) and leaf wetness duration (LWD) as the length of time this water remains on the leaf surface. LWD is one of the main factors influencing the appearance of plant diseases (Kim et al., 2002); and, in

Sci. Agric. (Piracicaba, Braz.), v.65, special issue, p.26-31, December 2008 
general, the occurrence and severity of diseases are more correlated with LWD than with rainfall (Reis, 2004). For example, many pathogens require the presence of water in the liquid form on the surface of the leaves in order to germinate their propagules and infect the host tissues (Gillespie \& Kidd, 1978). Under controlled environmental conditions, among the atmospheric variables, LWD was most dependent on relative humidity and relatively insensitive to temperature, net radiation and wind speed (Magarey et al., 2005).

Both field measurements and models have been used to estimate LWD. Under field conditions, LWD is commonly measured with sensors, but these provide an indirect measurement and there is variability between different makes of the sensors. Also the use of sensors for field measurements performed by growers is still restricted, due to their cost and difficulties involving handling, installation, maintenance and data downloading (Kim et al., 2002). On the other hand, on a regional scale, this parameter still lacks a quantitative and systematic description (Klemm et al., 2002). Most of the climatic stations worldwide do not record LWD and do not have sensors available (Madeira et al., 2002). Additionally, this variable is not easily measured (Santos, 2006).

Since surface wetness is not routinely measured by most National Weather Services, the ability to derive surface wetness data is of importance for experimentation or for operational use where field measurements are not available (Magarey et al.,
2005). Models can, therefore, serve as an alternative to determine LWD without the difficulties inherent to collecting data.

The objectives of this study were to estimate LWD, as a function of relative humidity, a parameter which is more easily found in meteorological station records, for climatological purposes and also to produce maps of mean monthly LWD and number of days per month with the presence of LWD, for a period equal to or higher than ten consecutive hours (ND), using a Geographical Information System - GIS.

\section{MATERIAL AND METHODS}

Data were obtained from ten meteorological stations located in cities with different climatic characteristics of the State of São Paulo: Adamantina $\left(21.685^{\circ} \mathrm{S}\right.$; $\left.51.073^{\circ} \mathrm{W}\right)$, Capão Bonito $\left(24.006^{\circ} \mathrm{S}\right.$; $\left.48.349^{\circ} \mathrm{W}\right)$, Campinas $\left(22.906^{\circ} \mathrm{S} ; 48.349^{\circ} \mathrm{W}\right)$, Jaú $\left(22.296^{\circ} \mathrm{S} ; 48.558^{\circ} \mathrm{W}\right)$, Pariquera-Açú $\left(24.715^{\circ} \mathrm{S}\right.$; $\left.47.881^{\circ} \mathrm{W}\right)$, Pindamonhangaba $\left(22.924^{\circ} \mathrm{S} ; 45.462^{\circ}\right.$ W), Pindorama (21.186 $\left.\mathrm{S} ; 48.907^{\circ} \mathrm{W}\right)$, Ubatuba $\left(23.434^{\circ} \mathrm{S} ; 51.073^{\circ} \mathrm{W}\right)$, Ribeirão Preto $\left(21.178^{\circ} \mathrm{S}\right.$; $\left.47.810^{\circ} \mathrm{W}\right)$, and Votuporanga $\left(20.423^{\circ} \mathrm{S} ; 49.973^{\circ}\right.$ W). The chosen cities are distributed evenly over the State of São Paulo (Figure 1). The years 1982, 1983, 1990, 1994, 1996, and 2000 were chosen because they had been considered typically humid (1983), dry (1994) and normal (1982, 1990, 1996, and 2000) years.

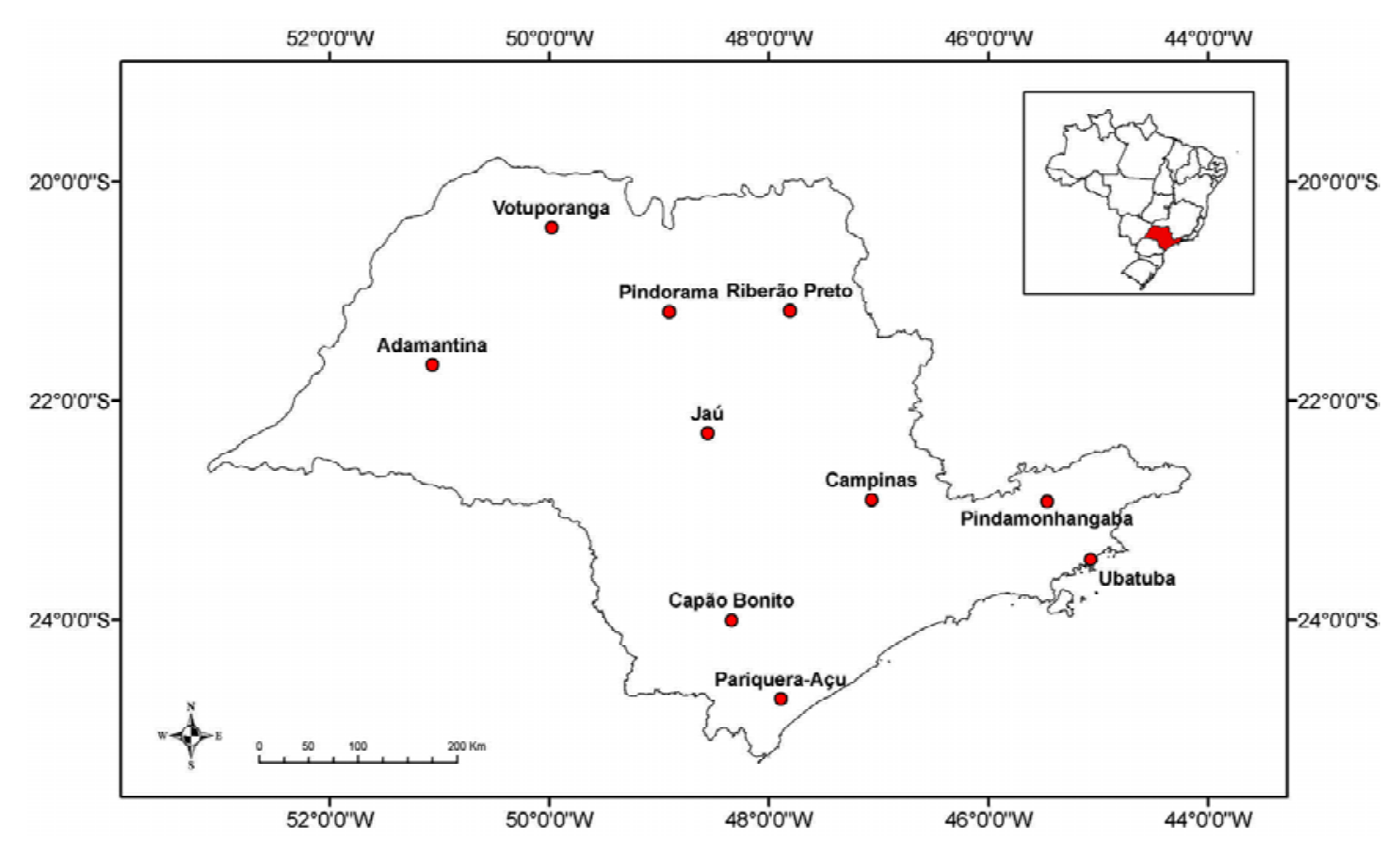

Figure 1 - Location of the meteorological stations used for adjustment of exponential functions, in the State of São Paulo, Brazil. 
LWD was obtained on a daily basis for each of these years and for each county using data from hygrothermograph charts and adopting an empirical method, assuming the occurrence of leaf wetness when the air relative humidity was above $90 \%$. This is a simple method and has become popular for the purpose of estimating LWD (Kim et al., 2002; Santos, 2006; Sentelhas et al., 1993; Sentelhas et al., 2004).

For every month, the quantity of hours in which relative humidity was equal to or higher than 90\% (LWD) and the number of days per month in which the relative humidity of the air was equal to or higher than $90 \%$, for a period equal to or higher than ten consecutive hours (ND) were registered. Afterwards, the data were related to the mean monthly relative humidity to obtain the LWD and the ND adjustment equations, using the linear, quadratic, and exponential regression methods in order to allow estimates of these parameters as a function of relative humidity, aiming the development of spatial distribution maps, considering different periods: a) April to September, dry and cold season; b) October to March, wet and warm season; and c) Annual.

The Geographical Information Systems software Idrisi 32, developed by the Clark University - USA was used to create maps of relative humidity for the periods, using data from the climatological normals from 1961 to 1990, in the State of São Paulo, obtained from the Climatic Research Unit (2006), originally with a spatial resolution of $10^{\prime} \times 10^{\prime}$ of latitude and longitude. The software Surfer was used to apply the ordinary kriging interpolation method and to generate relative humidity surface maps, with a spatial resolution of $0.01^{\circ} \times 0.01^{\circ}$ of latitude and longitude.

Following, LWD and ND maps were developed for the State of São Paulo for the periods: i) April to September; ii) October to March; and iii) Annual, applying the adjustment equations over the relative humidity maps, in the arithmetic module.

\section{RESULTS AND DISCUSSION}

To estimate LWD and ND as a function of relative humidity, regression equations were developed. The relationships between LWD and ND and relative humidity are shown in Figures 2 and 3, respectively. High values of coefficients of determination were observed $\left(\mathrm{R}^{2}\right.$ from 0.57 to 0.81$)$, indicating that LWD and ND can be estimated from relative humidity. For lower values of mean monthly LDW and ND, the equations give more precise estimates than to higher values. The obtained equations relating values of LWD and ND to relative humidity (RH) showed best fit through an exponential function as follows:

\section{a) April to September:}

$$
\begin{array}{ll}
\text { LWD }=0.0219 \mathrm{e}^{0.0744 \mathrm{RH}} & \mathrm{R}^{2}=0.81 \\
\mathrm{ND}=0.0051 \mathrm{e}^{0.0975 \mathrm{RH}} & \mathrm{R}^{2}=0.75
\end{array}
$$

b) October to March:

$$
\begin{array}{ll}
\text { LWD }=0.0506 \mathrm{e}^{0.0640 \mathrm{RH}} & \mathrm{R}^{2}=0.58 \\
\mathrm{ND}=0.0175 \mathrm{e}^{0.0828 \mathrm{RH}} & \mathrm{R}^{2}=0.57
\end{array}
$$

c) Annual:

$$
\begin{array}{ll}
\text { LWD }=0.0269 \mathrm{e}^{0.0718 \mathrm{RH}} & \mathrm{R}^{2}=0.75 \\
\mathrm{ND}=0.0067 \mathrm{e}^{0.0945 \mathrm{RH}} & \mathrm{R}^{2}=0.72
\end{array}
$$
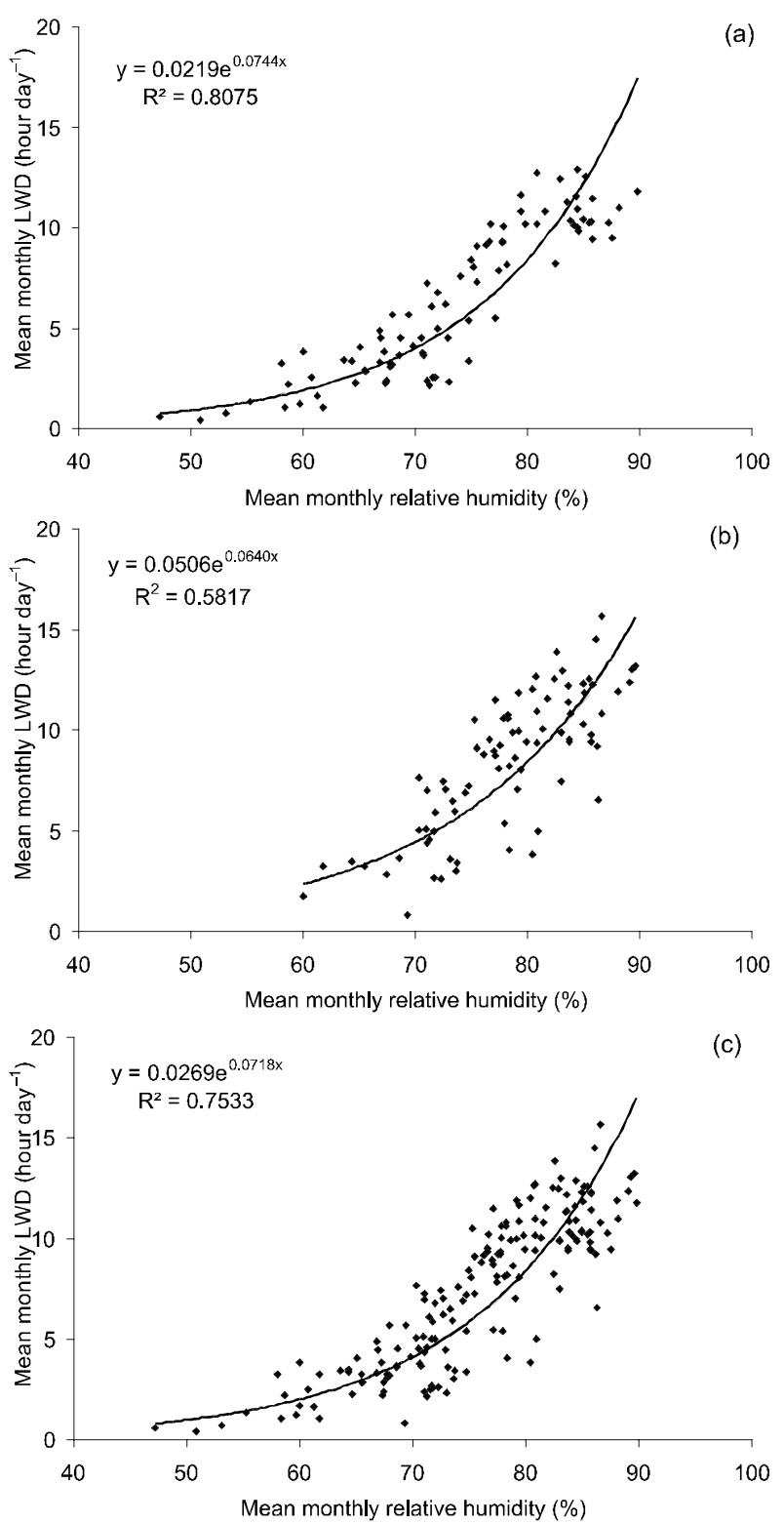

Figure 2 - Relationship between leaf wetness duration (LWD) and relative humidity for different periods: (a) AprilSeptember; (b) October-March; and (c) Annual. 
The equations to estimate ND are similar to the exponential equation developed by Pedro Júnior et al. (1989) to map the Microciclus ulei potential of infection of the different ecological zones for the State of São Paulo.

The mean relative humidity was characterized both spatially and seasonally (Figure 4), considering a drier season (autumn and winter) and a more humid season (spring and summer). In general, the drier weather was observed in the northwest and north of the State, with large areas where the mean relative hu-
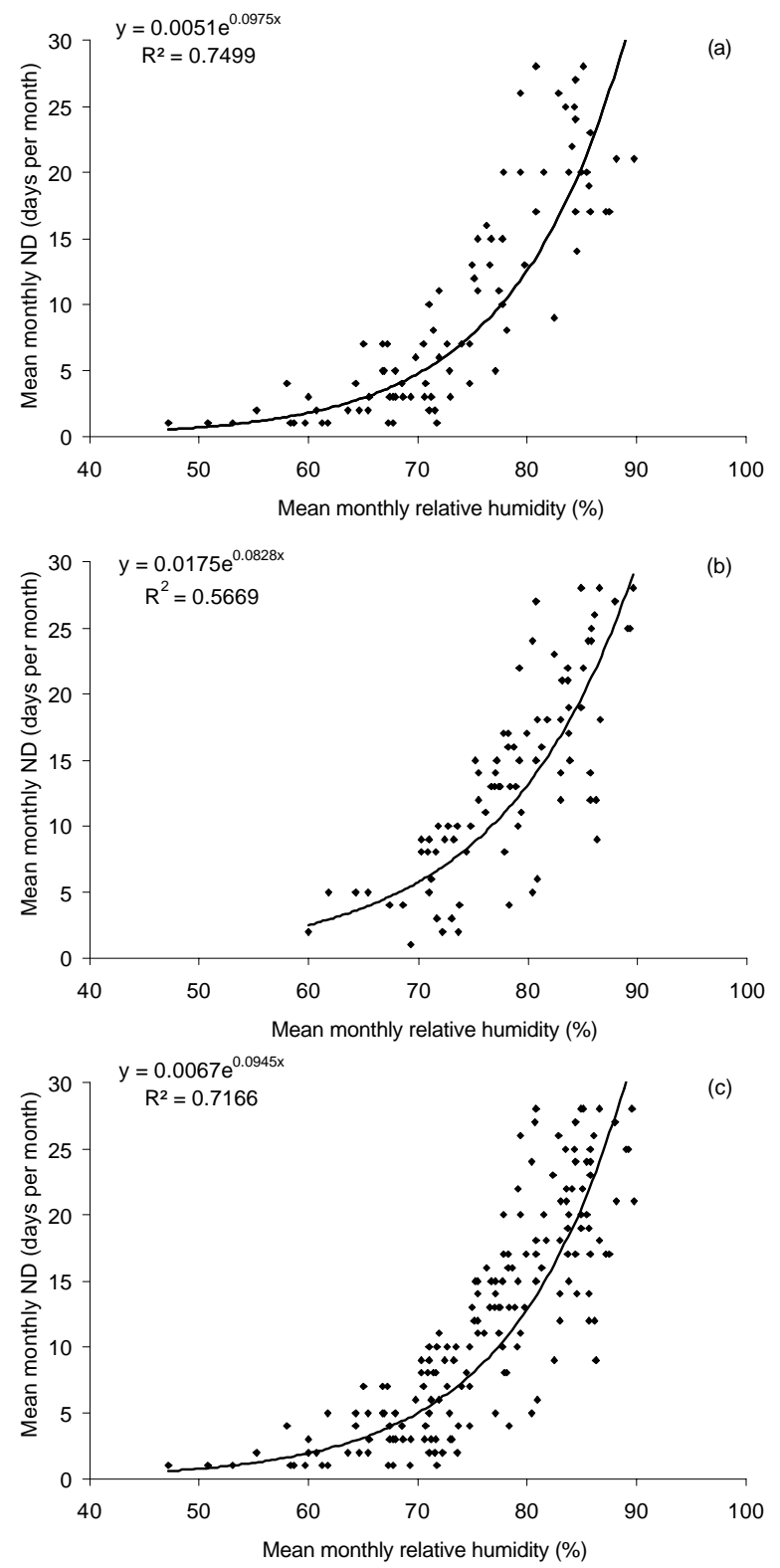

Figure 3 - Relationship between number of days (ND) per month with LWD for a period equal to or higher than ten consecutive hours and relative humidity: (a) AprilSeptember; (b) October-March; and (c) Annual. midity ranged from $60 \%$ to $70 \%$. For the most humid months, with relative humidity above $70 \%$, were observed throughout most the State (Figure 4).

The estimated mean LWD values changed among the different regions of the State and seasons of the year as expected, since they are direct functions of the relative humidity (Figure 5). The smallest estimated LWD values (1.5 to 3.0 hours day $^{-1}$ ) occurred predominantly from April to September (Figure 5). However, a predominance of areas with LWD

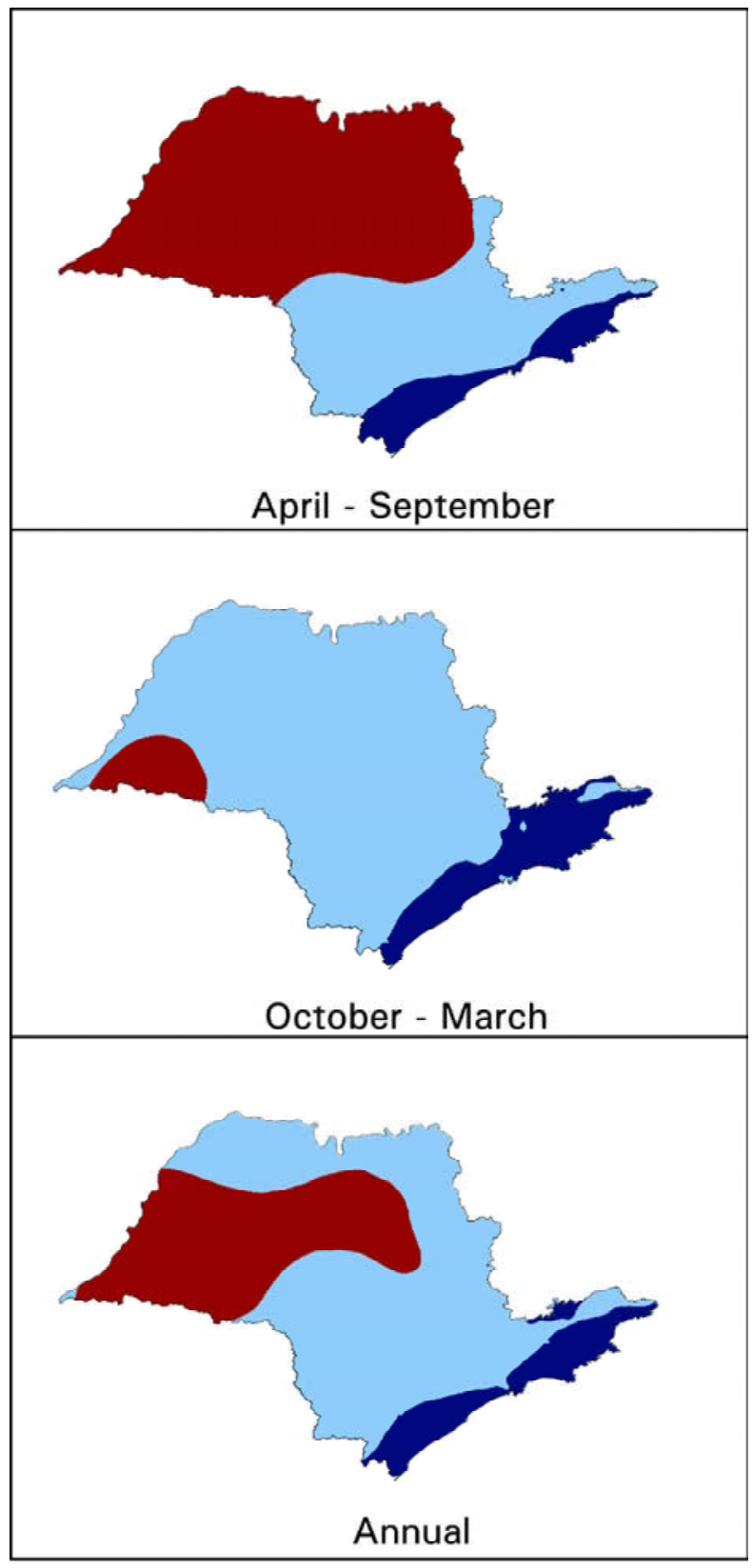

60-70 $\square 70-80 \square 80-90$

$90-100$

Figure 4 - Mean monthly relative humidity (\%) for the State of São Paulo for different periods of the year. Adapted from Climatic Research Unit (2006). 
higher than 6 hours day ${ }^{-1}$, from October to March was observed. In general, the south and southeast regions had the highest LWD values (more than 7.5 hours day $^{-1}$ ) throughout the year.

Autumn and winter, including the months from April to September, showed the smallest estimated ND values (Figure 6), in which with large areas presenting less than five days per month of ND. During spring and summer, from October to March, higher ND values were observed, showing a large area within the State presenting five to ten days per month.

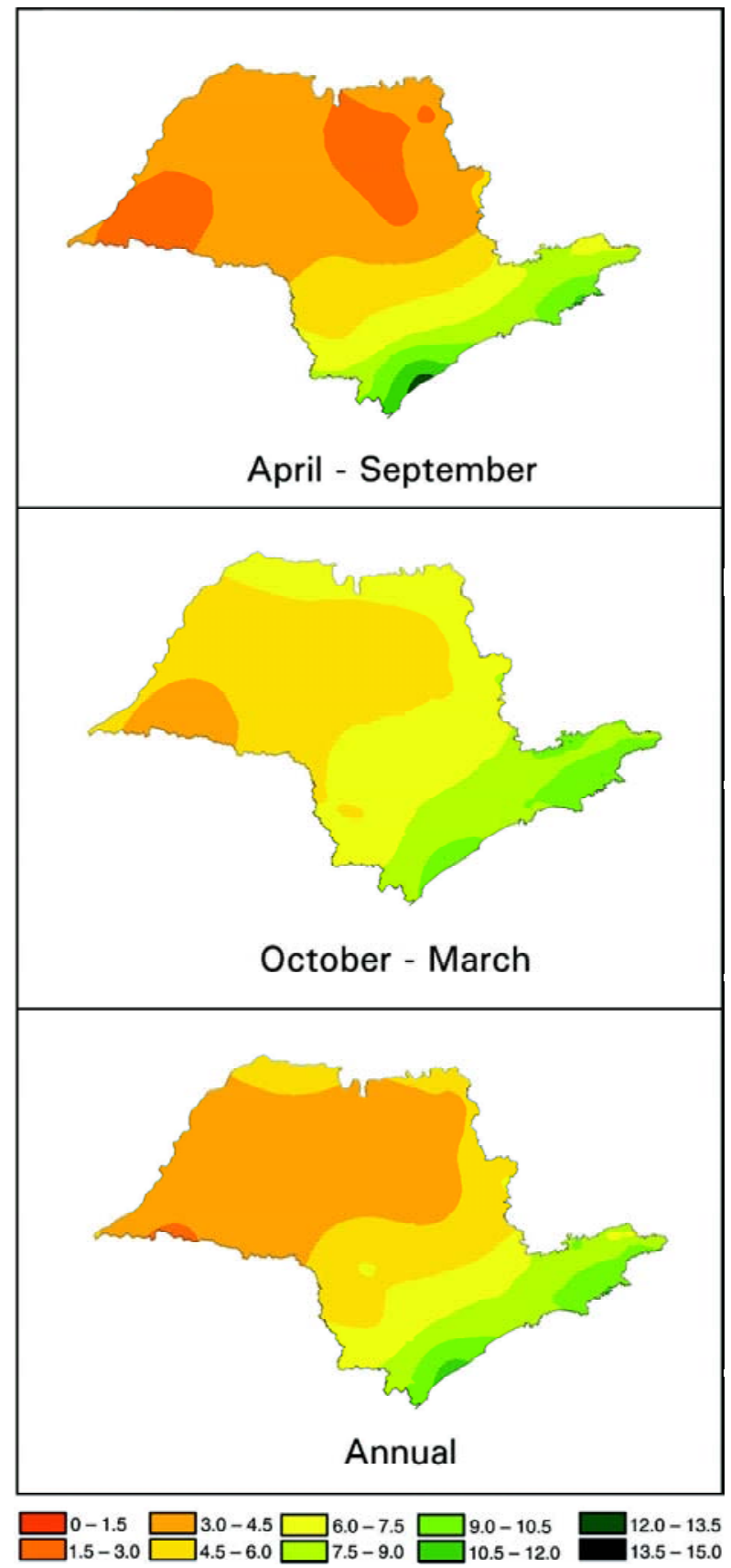

Figure 5 - Leaf wetness duration (LWD) in hour day ${ }^{-1}$ for the State of São Paulo for different periods of the year.
Dalla Marta et al. (2007) proposed an expert agrometeorological system to evaluate the development of Plasmopara viticola, an important disease of grapevine, on a regional scale, in part of Italy and Slovenia. A model for LWD based on the energy balance approach was applied using hourly meteorological data collected by a network of automatic weather stations. Nevertheless, a dense network of meteorological stations is not common in Brazil, on a regional or territorial scale. Plant disease zoning has recently been fa-

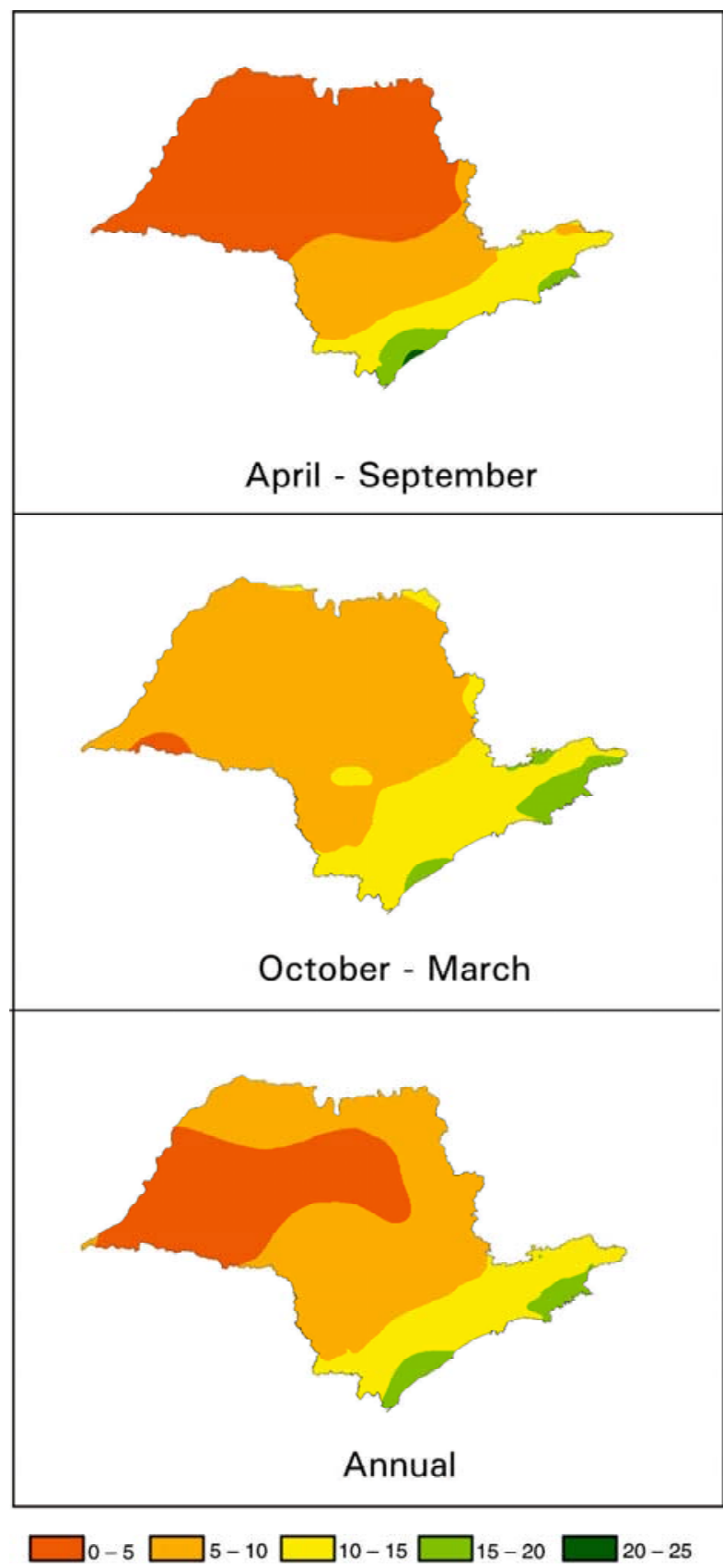

Figure 6 - Number of days (ND) per month with LWD for a period equal to or higher than ten consecutive hours for the State of São Paulo.

Sci. Agric. (Piracicaba, Braz.), v.65, special issue, p.26-31, December 2008 
cilitated by technological progress and GIS, which has made the manipulation of large georeferenced data bases relatively straightforward (Hijmans et al., 2000).

Once LWD and ND are important for plant disease development, maps of theses parameters for the State of São Paulo may help planners to choose areas where disease occurrence is expected to cause less damage to the crop. The proposed methodology allowed estimating LWD for the State of São Paulo, from relative humidity measurements, as well as estimating the ND, using the GIS tools. Results of this study made it possible to apply LWD and ND information on a regional scale. The exponential equations obtained to estimate LWD and ND as a function of relative humidity, which can easily be found in most of the standard weather stations, can be used as a tool to map and understand disease progress in different regions.

\section{ACKNOWLEDGEMENTS}

To $\mathrm{CNPq}$, for grant and scholarship given to authors and to Embrapa (Macroprograma), for financial support.

\section{REFERENCES}

CLIMATIC RESEARCH UNIT. Ten minute climatology: relative humidity. Available at: http://www.cru.uea.ac.uk/cru/data/ tmc.htm. Accessed 10 May 2006.

DALLA MARTA, A.; GANI, M.; CICOGNA, A.; DIETRICH, S.; ORLANDINI, S.; SANTORELLI, E. Transboundary system for grapevine downy mildew risk evaluation on a territorial scale (P. Rada project). EPPO Bulletin, v.37, p.290-294, 2007.

GILLESPIE, T.J.; KIDD, G.E. Sensing duration of leaf moisture retention using electrical impedance grids. Canadian Journal of Plant Science, v.58, p.179-187, 1978.
HIJMANS, R.J.; FORBES, G.A.; WALKER, T.S. Estimating the global severity of potato late blight with GIS-linked disease forecast models. Plant Pathology, v.49, p. 697-705, 2000.

KIM, K.S.; TAYLOR, S.E.; GLEASON, M.L.; KOEHLER, K.J. Model to enhance site-specific estimation of leaf wetness duration. Plant Disease, v.86, p.179-185, 2002.

KLEMM, O.; MILFORD, C.; SUTTON, M.A.; SPINDLER, G.; PUTTEN, E. van. A climatology of leaf surface wetness. Theoretical and Applied Climatology, v.71, p.107-117, 2002.

MAGAREY, R.D.; RUSSO, J.M.; SEEM, R.C.; GADOURY, D.M. Surface wetness duration under controlled environmental conditions. Agricultural and Forest Meteorology, v.128, p.111-122, 2005.

MADEIRA, A.C.; KIM, K.S.; TAYLOR, S.E.; GLEASON, M.L. A simple cloud-based energy balance model to estimate dew. Agricultural and Forest Meteorology, v.111, p.55-63, 2002.

PEDRO JÚNIOR, M.J.; ORTOLANI, A.A.; CHIAVEGATTO, O.M.D.P. Umidade relativa do ar para indicação do potencial de infecção do M. ulei em seringal adulto no estado de São Paulo. In: CONGRESSO BRASILEIRO DE AGROMETEOROLOGIA, 6., Maceió, 1989. Anais. Piracicaba: Sociedade Brasileira de Agrometeorologia, 1989. p.374-382.

REIS, E.M. Previsão de doenças de plantas. Passo Fundo: UPF, 2004. 316p.

SANTOS, E.A. Duração do período de molhamento foliar: medida com sensores eletrônicos, variabilidade espacial em culturas e estimativa com modelos empíricos. Piracicaba: USP/ESALQ, 2006. 56p. (Dissertação - Mestrado).

SENTELHAS, P.C.; GILLESPIE, T.J.; MONTEIRO, J.E.B.A.; ROWLANDSON, T. Estimating leaf wetness duration on a cotton crop from meteorological data. Revista Brasileira de Agrometeorologia, v.12, p.235-245, 2004.

SENTELHAS, P.C.; PEDRO JÚNIOR., M.J.; FELÍCIO, J.C. Estimativa da duração do período de molhamento para o trigo. Revista Brasileira de Agrometeorologia, v.1, p.117-122, 1993.

Received November 01, 2007

Accepted September 08, 2008 